\title{
Kernos
}

Revue internationale et pluridisciplinaire de religion grecque antique

$30 \mid 2017$

Varia

\section{A Copper Plaque in the Louvre (inv. AD 003732): Composite Amulet or Pattern-Book for Making Individual Body-Amulets?}

\section{Christopher A. Faraone}

\section{(2) OpenEdition}

1 Journals

\section{Electronic version}

URL: http://journals.openedition.org/kernos/2500

DOI: $10.4000 /$ kernos. 2500

ISSN: 2034-7871

\section{Publisher}

Centre international d'étude de la religion grecque antique

\section{Printed version}

Date of publication: 1 October 2017

Number of pages: 187-220

ISSN: 0776-3824

\section{Electronic reference}

Christopher A. Faraone, « A Copper Plaque in the Louvre (inv. AD 003732): Composite Amulet or Pattern-Book for Making Individual Body-Amulets? », Kernos [Online], 30 | 2017, Online since 01 October 2019, connection on 17 September 2020. URL : http://journals.openedition.org/kernos/2500 ; DOI : https://doi.org/10.4000/kernos.2500

This text was automatically generated on 17 September 2020.

Kernos 


\title{
A Copper Plaque in the Louvre (inv. AD 003732): Composite Amulet or Pattern-Book for Making Individual Body-Amulets?
}

\author{
Christopher A. Faraone
}

\section{Introduction}

1 An exhibition in Paris in the year 2000 displayed a small plaque (Fig. 1a-b) cut from thick sheet of copper alloy in the shape of an aediculum or miniature shrine. ${ }^{1}$ It was purchased in Egypt, probably near Luxor, and in the 1840s it was donated by Prisse d'Avesnes to the Bibliothèque Nationale in Paris, whence it eventually made its way into the Egyptian collection of the Louvre. ${ }^{2}$ The plaque is engraved on both sides with a total of six images, all but one encircled by Greek letters or symbols. In the exposition catalogue Marc Étienne described the object as a "Coptic talisman with magic drawings and inscriptions" and dated it to the ninth century CE, in part because of the Arabic inscription on the top left corner of the obverse. ${ }^{3} \mathrm{He}$ also noted in passing that three of the images on the plaque resemble those found on Roman-period amulets: the lionheaded serpent called Chnoubis, the Pantheos, and a well-known scene of Horus treading on the crocodiles. ${ }^{4}$ More recently, Árpád Nagy and Véronique Dasen noted that the name of "Chnoubis" also appears on the tablet, as well an image of a lizard that we often find on amulets used to cure eye disease; they describe the object as "une lamelle-amulette". ${ }^{5}$ But aside from this passing mention of the name of Chnoubis, no one, to my knowledge, has examined the texts in close detail, questioned why they encircle five of the six images or discussed how they and the images have been misunderstood and transformed in Late-Antiquity or in the early medieval period.

2 The consensus seems to be, then, that this copper plaque was used as some kind of amulet, but if so, what kind of amulet? It is two millimeters thick - too thick and stiff 
to be rolled up and placed in an amulet case and for that matter too large and heavy to be worn comfortably as a body-amulet: it measures $9.7 \mathrm{~cm}$ in height and $5.2 \mathrm{~cm}$ in width, which makes the rectangular portion of it about the size of a modern playing card or pack of cigarettes. Its dimensions, the large hole at the apex, and the signs of wear on the reverse all suggest, on the other hand, that it was hung on a wall with the Arabic inscription facing outwards and used as an amulet for a house or a shop. Unfortunately, as we shall see, there is a contradiction between the various purposes of the six images on the plaque: four were designed to heal bodily diseases and only two were used to protect. I shall argue, in fact, that the plaque is not itself an amulet, but rather a handbook or pattern-book originally designed to be hung on the wall of a studio in order to remind an artisan how to carve or draw the six images and the texts that accompany them.

3 I shall begin, then, by showing that four of these images (the lizard and the three designs that include the Chnoubis snake), as well as the voces magicae that surround them, closely reflect the combination of image and text we find in the corpus of magical gems, albeit with some graphic errors in the texts as well as some additions, including perhaps a Coptic invocation to "the Savior". I then discuss the two remaining protective designs, both stemming from the late Pharaonic tradition, where we find similar scribal errors, as well as significant changes in the images, that aimed, it seems, at removing the more outlandish parts of the original Egyptian design. I close by suggesting that the designs on this early medieval plaque were transformed over time from a Greek pattern-book originally composed in the Roman period and therefore give us important insight into the transmission of amulet-lore in a form quite distinct from the recipes which we find in the better known papyrus-handbooks discovered in the same area in late-antique Egypt.

\section{The Lizard}

The lizard appears on the lower half of the reverse side of the plaque in an aerial view, and the artist has carefully rendered its scales and digits (Fig. 2a). As Nagy and Dasen noted in passing, this image closely recalls a popular design on magical gems used to cure eye disease, as we see, for example, in Fig. $2 b$, where the lizard's head is pointed into the concave side of a crescent moon and a single Greek letter, pi, eta, rho, or alpha, has been inscribed at each of its feet. Most of these gems also have a short Greek inscription kanthe soule on the reverse, usually divided into the two parts as we see in Fig. 2c. We know that this design was used to cure eye disease thanks to a recipe in a late Roman lapidary called the Cyranides, which is the last witness - after Pliny and Aelian - to a bizarre ritual for making curative rings. ${ }^{6}$ This recipe tells us to blind a green lizard with two nails and then seal the animal, its gouged eyes, and the nails in a ventilated pot with soil until the lizard regains its sight, at which point we are to release him and fashion from the nails two identical rings as follows: ${ }^{7}$

...make the nails into rings and... enclose in these rings a jasper stone that has a carved lizard stretched out on its stomach and is inscribed peira. Beneath this the name chouthesoule. ${ }^{8}$ For (in this way) you will be unharmed in your eyes for all your years and you will heal ophthalmia suffers by fastening them to the ring.

Comparison with the magical gem (Fig. $2 b$ above) reveals a close match:

Gems: П-H-P-A KANOE $\Sigma$ OY $\Lambda$ E

(one at each foot) (on back of gem) 
Cyranides: ПEIPA XOY $\Theta \mathrm{E}$ OY $\Lambda \mathrm{E}$

(on obverse) ("beneath" ПЕIPA)

There are some important differences: the author of the Cyranides does not mention the crescent moon above the lizard's head, ${ }^{9}$ and he or his source did not understand that we were supposed to place a single Greek letter at each of the lizard's feet - a pi, an eta, a rho, and an alpha - rather than inscribe the letters as the single word peira, which in the Roman period probably reflects the original spelling pera. Finally, the text of the second inscription recommended by the Cyranides recipe - chouthesoule - differs slightly from what we find on the gem, as does its position "beneath" the word peira, rather than on the reverse side of the stone..$^{10}$ The Cyranides recipe, in short, advises us to engrave the image and all of the text on the same side of the gem and presumably leave the reverse blank.

We see similar kinds of differences in the lizard-design on the Paris plaque (above in Fig. 2a), which dates to a period even later than the Cyranides. The crescent moon, for example, has been squared off around the lizard's head, and, although the single letters are placed in their appropriate positions, they have been corrupted or transformed: next to its front feet we find the Greek letter omega (instead of the expected pi) and then the expected êta, albeit so inexpertly engraved that it resembles a reversed $n \hat{u}$. Near the rear legs we find two more letters: on the left side there is a design that looks like the Greek letter koppa, instead of the expected rho, and near its right foot we see an oversized and misshapen alpha. The inscription that encircles the animal likewise shows both continuity and change. If we begin near the left side of its head we get a sequence of ten letters that closely resembles the two words kanthe soule found on the back of most of these stones:

Gems: KANOEEOYAE

Cyranides: XOY $\Theta E \Sigma O Y \Lambda \mathrm{E}$

Paris Plaque: K $\triangle \mathrm{NB} \Sigma \Sigma O Y \Sigma \mathrm{E}$

7 The early medieval creator of the copper plaque (or his source) made or reiterated errors sometimes found on the gemstones of the Roman period, for example: delta for alpha or lunate sigma for epsilon. The use of a retrograde beta for theta is, however, unusual. The second word soule is correctly transcribed, except that the fourth letter lambda has been rotated to the left so that it looks like a pointed sigma.

8 Generally speaking, then, the errors in the text on the copper plaque are graphic, not phonic: delta for alpha, beta for theta, and the lunate sigma for epsilon. But after his version of the magical words kanthe soule, the artisan or his source improvises. He first inscribes a leaf, followed by letters that seem to be without any coherent meaning in Greek and without any parallels among the many nonsense words found on other Greek amulets: an upside-down pi, a six-pointed star, two koppas - the second with a base followed by three Greek letters: iota, sigma, and kappa. The second half of the encircling inscription has no parallels with the many nonsensical magical words on amulets and the triple appearance of the archaic letter koppa is significant, but perhaps not as bizarre as it might seem at first glance, because the koppa continued to be used in Coptic and Byzantine texts as a number. ${ }^{11}$ As we shall see below, other arcane scribal symbols, numerals and scribal ligatures are used elsewhere on the plaque to fill out the traditional voces magicae. In the end, then, the amulet design of the lizard on the Paris plaque combines, as does the Cyranides recipe, text and image into the single oval design. 


\section{The Lion-Headed Serpent Called Chnoubis}

Scholars have also noted in passing the presence of both the image and the name of Chnoubis on the plaque, ${ }^{12}$ which in fact appears in three different guises in the lower circles on the obverse side. We begin with the version on the pedestal (Fig. 3a) because, as in the case of the lizard, we find clear parallels between the copper plaque and the magical gems, as for example, the magical gem in Paris illustrated in Fig. 36 . The text engraved on the circumference of the Paris gem is an extended invocation of the god on the pedestal and similar words appear, in fact, both on the periphery of another gem in Berlin and on the copper plaque directly beneath the image of Chnoubis on the pedestal (Fig. 3c): ${ }^{13}$

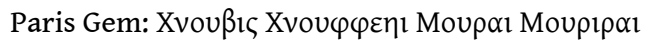

Berlin Gem: Xvoußৎ Xvoupı

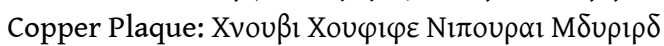

10 If we look closely at the inscription as it travels along the edge of the gem in Paris (Fig. 3a), we can see that the carver left spaces between these four words that correspond exactly with the line-by-line division of the same four words on the plaque (Fig. 3c). Both, therefore, must derive from the same tradition. The Berlin gem does not, however, divide the text at these points. The Paris and Berlin gems seem to be, moreover, the only gems with Chnoubis on the pedestal that also carry this inscription, although nearly all of the other gems do carry some version of the name Chnoubis or other epithets typical of the lion-headed snake. ${ }^{14}$ We see once again multiple graphic errors or variants on the copper plaque: the second word is missing some letters and the start of the third word on the plaque has been badly corrupted. The final word on the plaque twice substitutes a delta for an alpha, which is the same mistake we saw in the kanthe soule inscription around the lizard. In this case, however, the text that surrounds the image on the two gems is found below the image on the copper plaque, not around its periphery. ${ }^{15}$ The text that encircles the image on the plaque, on the other hand, is entirely different and, as far as I can tell, unparalleled among the magical logoi found in the magical papyri, on the lamellae or on the gems (beginning near the top of the serpent's head): PEY $\Sigma O N$ PH $\Sigma \Omega P ~ H N \Sigma \Lambda$ X $\Omega O O X O N X .^{16}$

The most common image of Chnoubis on the magical gems, however, depicts the god alone without a pedestal and accompanied only by his name and a special symbol (ssS ), as we can see, for example, on the back of the gem in the British Museum illustrated in Fig. 4a, which records his name in the common variant Chnoumis, instead of Chnoubis. We know that in the Roman period these gems were thought to be curative, because Galen tells us so: ${ }^{17}$

The testimony of some authorities attributes to certain stones a peculiar quality, which is actually possessed by the green jasper. ${ }^{18}$ Worn as an amulet, it benefits the stomach and the esophagus. Some set it in a ring and engrave on it a radiate serpent, just as King Nechepsos ${ }^{19}$ prescribed in his fourteenth book. Of this stone I, too, have personal experience. I made a string of small stones of this type and hung it from my neck at such a length that the stones touched the esophagus. They seemed no less beneficial, even though they had not the design that Nechepsos prescribed.

This "design that Nechepsos prescribed" appears, as was mentioned earlier, in another circle on the copper plaque, this one in the bottom right corner of the obverse side 
(Fig. 4b). The image is rather scrawny and schematic, but it is essentially the same as that found on the gems, where the serpent almost always has a single loop in its tail. And like the lizard image, this Chnoubis is encircled on the plaque by Greek letters that start off with a traditional text that we usually find on the reverse of these gems, although it has been transformed. Beginning with the letter chi near the back of the serpent's head and running downwards, we find a distorted version of the god's name $(\mathrm{X} \pi \omega \cup \beta \varsigma)$ that, like the Berlin gem discussed above (Xvou $\beta$ ), lacks the iota. It is also followed by XXX, which is, I suggest, a corrupt or inept rendition of the Chnoubis sign ( SSS-). As in the case of the inscription around the lizard, the remainder of the encircling text on the copper plaque has been filled in with nonsensical letters and symbols that as a sequence are not attested elsewhere in the Greek magical tradition: a reversed rho, a broken omega, two iotas, a diamond shape and a symbol that looks like an upside-down ligature of lambda and pi. Given the use of the numerical sign koppa thrice in the lizard-design, it may well be that this ligature has also been borrowed from the world of accounting: it is the scribal abbreviation for the Greek word "sum" ( $\pi \lambda \tilde{\eta} \theta 0 \varsigma)$, preceded, perhaps, by notations of weight. ${ }^{20}$ But it is most likely, of course, that here, too, these abbreviations or symbols are stripped of their traditional semantic values and are being used simply as mysterious signs to fill out the circle of magical names. On the other hand, the final five letters in the circle of text - beginning with the inverted psi and then omega - may well be a version of a well-known Coptic epithet of Jesus as "the savior" ( $\psi \omega \tau \eta \rho)$, which would, of course, be an appropriate addition to the divine names of a radiant-headed solar god like Chnoubis. ${ }^{21}$ Both here and in the letters surrounding the lizard, then, the creator of this plaque or his source apparently felt compelled, perhaps for aesthetic reasons, to encircle each of the images completely, even if the traditional text inscribed on the back of the gems did not have enough letters to do so.

The third design that uses the Chnoubis-serpent appears to the right of the image of the god on the pedestal (Fig. 5a): we see a person with a round frontal head and features similar to the two other humanoid figures on the plaque striding to the left and gripping in his right hand a miniature version of the Chnoubis serpent, as if it were a staff made of metal or wood. This Chnoubis-staff is difficult to make out in miniature, but we can make sense of it, if we compare it to similar images on a series of gemstones, like the gem in Florence in Fig. 5b, that shows the Chnoubis-staff in the right hand of a lion-headed god. This god, sometimes called Heliorus, has a profile head and usually carries another object down by his left thigh, for example, an ankh-sign, a situla, or, as we see in Fig. 5b, two ears of grain held with their tops pointing downwards. I suggest, in fact, that this Florentine gem has the precise Roman-period design that lies behind the figure on the copper plaque, with one important change: the lion's head has been replaced by a human one and the ears of grain look more like a single palm branch. We

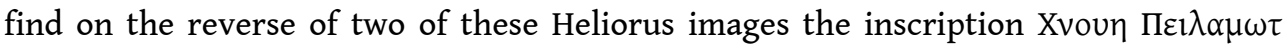
$\Phi \rho \eta v$ (Fig. 5c), which is a perfectly good solar invocation, beginning, as it does, with another version of the name of Chnoubis and ending with the name of the Egyptian solar god Re. ${ }^{22}$ But this is not the text that we find encircling the same image on the copper plaque, the sense of which eludes us, perhaps because the scribe changed the direction of the letters midstream. ${ }^{23}$ 


\section{The Horus Cippus and the Pantheos}

holding two upright poles, as if he were cross-country skiing and skipping at the same time (Fig. 6a). In the exhibition catalogue Marc Étienne aptly suggested that this was a stripped-down version of the so-called "Pantheos" or polytheistic deity that appears on many protective amulets, ${ }^{24}$ as, for example, on a gem in the British Museum inscribed with a prayer for protection (Fig. 6b) or a thunderstone-amulet in Toronto that protected a house from lightning (Fig. 6C). ${ }^{25}$ The figure on the copper plaque is, of course, a pale imitation, as it only replicates the two upright staffs held in the hands of the god, while ignoring the wings and the various animal heads and vegetation that usually protrude from the top of Pantheos' head or from the sides of his neck. Like the suppression of the lion's head on the figure holding the Chnoubis-staff discussed earlier, this may have been another effort to "clean up" the image and make it more acceptable to late antique and perhaps Christian clients. No Greek text, circular or otherwise, is associated with this image, although the as-yet-undeciphered Arabic text may be connected with this image by its proximity. ${ }^{26}$ There is, however, a puzzling object beneath the left foot of this figure, which is, I suggest, a truncated version of the rectangular shape created by the ouroboros serpent that one sometimes finds below the feet of the Pantheos, as you can see on the gem in Fig. $6 \mathrm{~d}$.

Étienne also pointed out that the final image on the copper plaque (Fig. 7a), that of a person standing on top of a snake and feline, was originally inspired by another popular late-Pharaonic image, the child Horus as he appears on hundreds of statuettes or cippi that were used in Egypt to protect people or their homes from scorpions, snakes and other dangerous animals. We see the standard scene in Fig. 7b: the child Horus stands on a pair of crocodiles and grips in each hand two snakes and a scorpion, as well as the tail of a tiny lion in his left hand and the horn of a tiny ibex in his right. The god himself is naked, and his head is shaved, except for the so-called Horus lock that hangs down behind his right ear. The mask of the god Bes, yet another apotropaic device, sits on top of his head.

The figure on the copper plaque in Paris does indeed recall some of these details: he is bald, and near to his left ear there appears to be a poorly drawn lock of hair, but on the wrong side of his head. There is, however, no clear indication that this person is a child, and, in fact, in size and shape he differs little from the two other humanoid figures on the plaque, although the artisan did add nipples to the Horus figure, an attempt, 
perhaps, to stress that he alone is naked. This figure does not, however, grasp any animals in his hands, as Horus does in the standard scene, but rather, he holds a downward-pointing branch, much like the object held by the Heliorus figure discussed above. I suggest that this "branch" may, in fact, be a poorly drawn scorpion grasped by its tail, as we can see in an equally poor image carved on a gem of Roman date (Fig. 7c) that is also said to come from Egypt: ${ }^{27}$ a naked Horus standing on two small and facing crocodiles and holding a scorpion by the tail in his right hand and an ibex in his left. This gem image has also been "cleaned up" a bit: the lock of hair is gone and the palmette on top of his head replaces the usual Bes-mask. The Greek prayer on the reverse reveals the protective force of the image: "Lord Akrimakrageta help and protect the wearer from every creeping thing!" This image suggests, then, that the branch held by "Horus" on the copper plaque was originally meant to be a scorpion.

But what are we to make of the snake and lion beneath the feet of Horus, precisely where we expect to find the crocodiles? Both make good sense as replacements, of course, because on the traditional cippi they are also suppressed, albeit in a different manner: grasped firmly in the hands of the child-god. That these animals have simply been moved about within the original design is suggested by the fact that the lion who dangles from Horus' hand on the traditional cippus (Fig. 7b) often looks back over its shoulder, just like the lion on the copper plaque. I suggest, moreover, that the person who replaced the crocodiles with the lion and the snake had in mind the words of

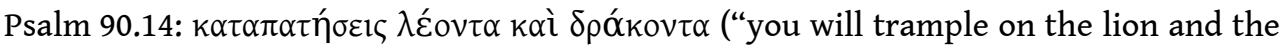
snake") or the images of Jesus that these words inspired, for example, in the famous sixth-century mosaic in the Archbishop's Chapel in Ravenna (Fig. 8a). Verses from Psalm 90, of course, were extremely popular on Christian amulets and an unpublished Byzantine amulet that quotes the verse 9-11 of the Psalm on the reverse, shows Jesus on the obverse (Fig. 86 ) hovering, like the Horus-figure on the Louvre plaque, over a lion and a snake, although in this case the lion appears above the snake and thus correctly follows the word-order of the Psalm. ${ }^{28}$ In these images Jesus sometimes holds in his right hand a spear or a cross, so perhaps the object in the right hand of the Horus figure on the plaque was meant to be a palm branch, another important symbol of victory. ${ }^{29}$

\section{Conclusion}

19 We have seen, then, that the copper plaque in Paris preserves six different amuletic designs from two somewhat different traditions. The Pantheos and the Horus on crocodiles are older, Pharaonic images designed to protect, and on the copper plaque they have no firm connection with the traditional magical names that we find on the gems - indeed, the Pantheos figure has no text surrounding him at all. The images of Chnoubis and of the lizard, on the other hand, are later inventions of the Hellenistic or Roman period, and generally aim at curing diseases. And aside from the suppression of the lion-head of the Heliorus figure, these images are hardly changed at all.

These six designs do not, then, cohere as a single amulet and I suggest, instead, that this plaque originally served as a pattern book or handbook to guide a gem-cutter in the complicated task of engraving magical gems with both images and the texts that go with them. One can, perhaps, imagine, too, that he had hanging on the wall of his shop other copper plaques of similar shape, each inscribed with a different set of designs. 
Side A is especially interesting because all four images are between 2 and 2.5 centimeters tall - that is, roughly equivalent to the size of the same images on the gems themselves. ${ }^{30}$ The grouping together of the three images of Chnoubis may also be a feature of these pattern-books, similar to curative handbooks, for example, where we often find two or three recipes in a row dealing with the same ailment or lapidary handbooks, which sometimes repeats the type of stone in the rubric. ${ }^{31}$

21 The Arabic inscription, finally, shows us clearly that this copper handbook is of early medieval date or later (Fig. 9). Although the individual letters are in some cases fairly easy to read, the text lacks the important diacritical marks used to distinguish some letters from others and one non-traditional sign appears twice - above line 3 and at the very end of line 4: it looks somewhat like an inverted and elongated omega. I suspect, in fact, that these Arabic letters and the two symbols are yet another series nonsense words, like those rendered in Greek elsewhere on the plaque, and that they were supposed to be inscribed on a gem engraved with the image of the Pantheos, who appears to the right of it and is otherwise unassociated with any inscription. Because this Arabic text is divided into four nearly equal parts, like the four words engraved below the image of Chnoubis on the pedestal, it may well be the case that, like the Greek words, they were supposed to be inscribed around the edge of the image of the Pantheos.

Despite the gap of at least five hundred years between the copper plaque and the magical gemstones we have used as comparanda, we saw that the Chnoubis and lizard images on the plaque and some of their inscriptions are quite similar in design to their Roman-period ancestors, suggesting that these designs persisted relatively unchanged well into the Middle Ages. We need not be astonished, of course. The Cairo Geniza shows us clearly that in Egypt, at least, Greek textual amulets survived and were transformed into Aramaic in the Middle Ages; ${ }^{32}$ and thanks to the work of Gary Vikan and others, we can document the survival of the Chnoubis-serpent well into the middle Byzantine period on bronze and gold jewelry. ${ }^{33}$ But the copper plaque in Paris also reveals a good number of interesting transformations of these traditional images, most importantly, as we saw, the suppression of wings, non-human heads, and other Pharaonic motifs, a change motivated, perhaps, by a scruple against mixing human and animal forms, for we saw in contrast that the serpent Chnoubis was allowed to retain his lion-head, as he does on Byzantine amulets. ${ }^{34}$

Most of the texts on this plaque also have clear antecedents among the nonsensical magical words of the Roman period, but again the passage of time has encouraged both modifications and additions. We were able, however, to see some logic or code in the relationship between the design on the plaque and the earlier gems. In two cases - the simple Chnoubis and the lizard - half the words that encircle the image on the plaque are found on the reverse of the earlier gems that bear the same image. In the case of the man holding the Chnoubis staff, however, the words inscribed in four lines beneath the scene were apparently meant to encircle the image. These arrangements make sense, of course, as a clever device for saving space in a pattern-book, as long as the gem-cutter remembers the code. But at some point, between the Roman-period original and this post-Conquest version, someone added nonsense letters or symbols to fill out the traditional texts associated with the lizard and the Chnoubis. We saw, moreover, that these added texts also showed possible signs of Christian influence, for example, the Coptic acclamation "the Savior", but most telling of all was the transformation of 
Horus on the crocodiles into Jesus treading upon the snake and lion. It is difficult, of course, to assign these changes to any specific time period or individual, because like most handbooks, this pattern-book seems to have been a continual "work in progress", as the artisans, who used it and copied it, presumably adapted their wares to new trends in visual design and media and to the private wishes of their clientele. But it is truly extraordinary that so many of these original images and texts persisted in recognizable form for so long.

FIg. 1A. PHOTOgRAPH OF PARIS COPPER PLAQUE (LOUVRE) 
FIg. 1B. DRAWINg OF PARIS COPPER PLAQUE (D. MERTES)

FIg. 2A. DRAWINg Of LIZARd ON PARIS COPPER PLAQUE (D. MERTES) 
FIg. 2B. LIZARD ON OBVERSE OF gEM IN PARIS (DD 366)

FIg. 2C. MAgICAL NAMES ON REVERSE OF gEM IN PARIS (DD 366)

Kernos, 30 | 2017 
FIg. 3A. DRAWINg Of ChNOUBIS ON PEDESTAL ON PARIS COPPER PLAQUE (D. MERTES)

Fig. 3B. ChNOUBIS ON PEDESTAL ON ObVerse OF gem In PARIS (DD 79) 
FIg. 3C. DRAWINg OF GREEK TEXT UNDER CHNOUBIS ON THE PEDESTAL ON COPPER PLAQUE (D. MERTES)

FIg. 4A. CHNOUBIS ALONE, HIS NAME AND SYMBOL ON gEM IN LONDON (BM 305 = CBD 691) 
FIg. 4B. DRAWINg OF CHNOUBIS ALONE ON OBVERSE OF COPPER PLAQUE (D. MERTES)

FIg. 5A. DRAWINg OF PERSON WITH CHNOUBIS STAFF ON COPPER PLAQUE (D. MERTES) 
Fig. 5b. Heliouros w/ Chnoubis staff on obverse of Florence gem (SGG FI 42)
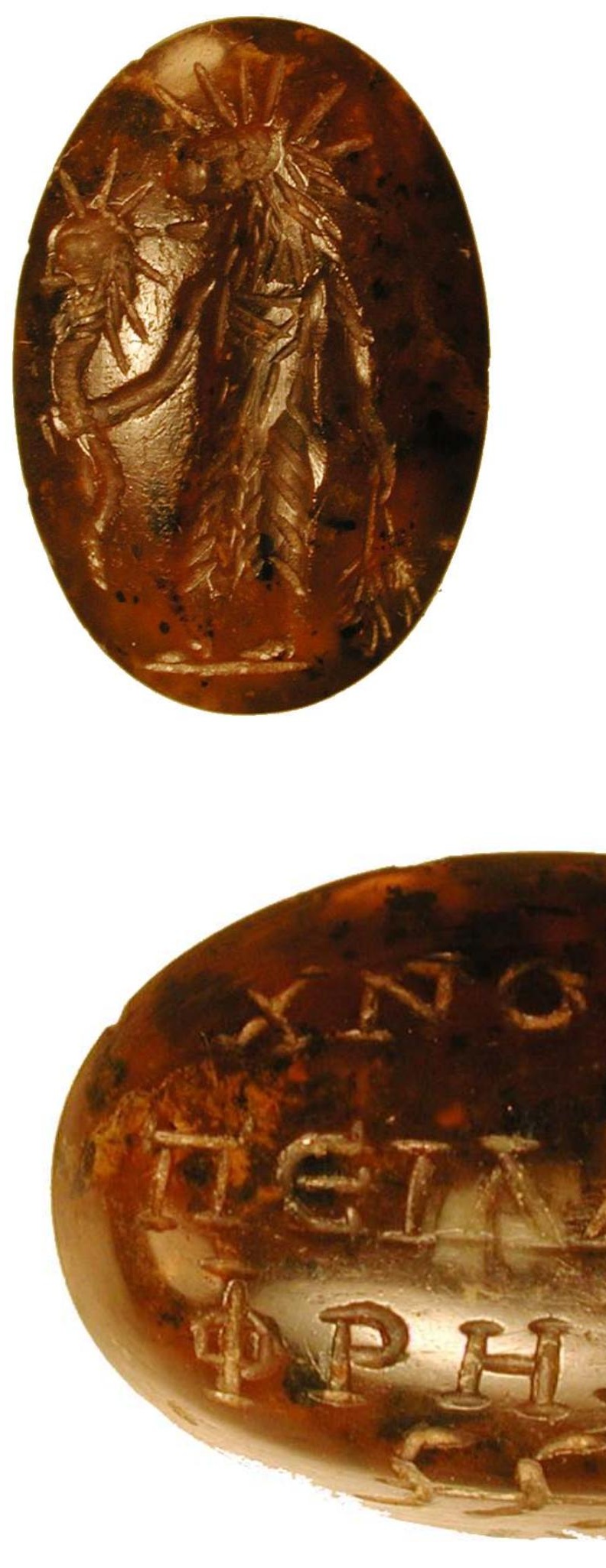

Fig. 5c. Magical names on reverse of gem in Florence (SGG FI 42) 
FIg. 6A. DRAWINg OF PANTHEOS ON PARIS COPPER PLAQUE (D. MERTES)

FIg. 6B. PANTHEOS ON gEM IN LONDON (BM 289 = CBD 675) 


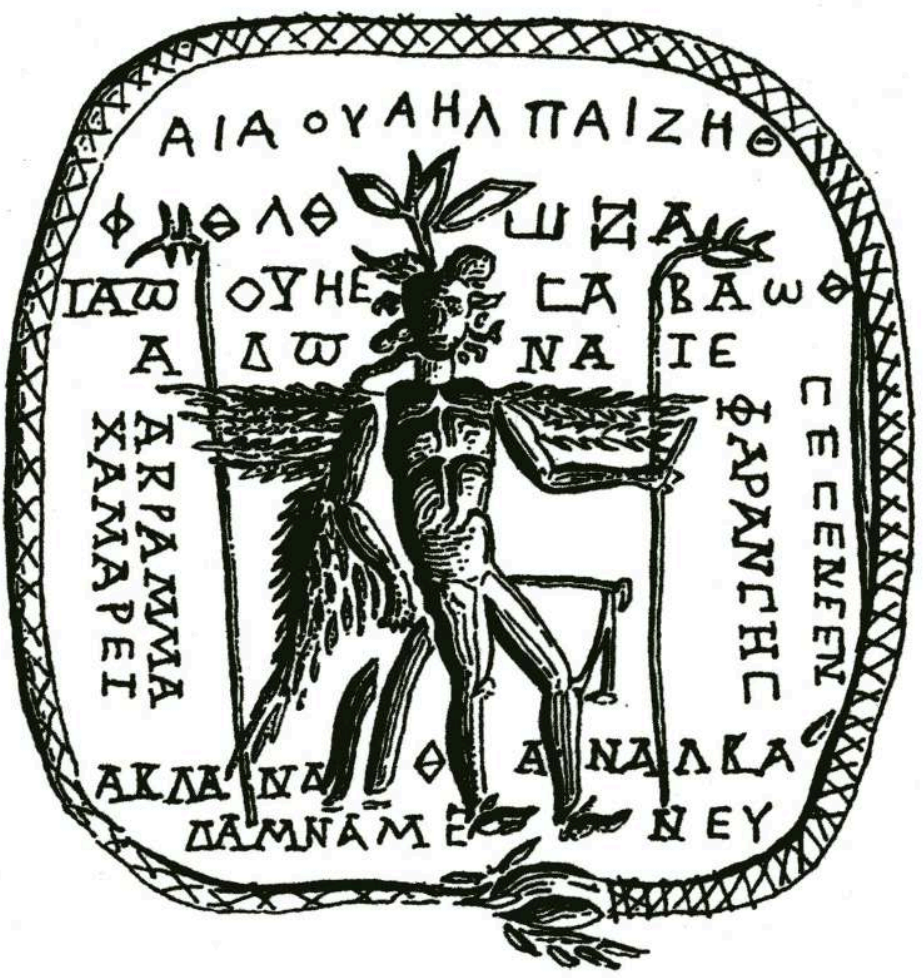

Fig. 6c. Drawing of Pantheos on Toronto thunderstone; drawing after J.H. ILIFFE, "A Neolithic Celt with Gnostic Inscriptions at Toronto," AJA 35 (1931), p. 304-309.

Fig. 6D. PANTHEOS AND OUROBOROS ON gEM IN LONDON (BM 161 = CBD 559). 
FIg. 7A. DRAWINg OF HORUS WITH SIDE-LOCK TREADINg ANIMALS ON COPPER PLAQUE

FIg. 7B. STATUETTE OF HORUS TRAMPLINg CROCODILES IN BROOKLYN (INV. 60.73_SL1) 
FIg. 7C. DRAWINg OF HORUS TRAMPLINg CROCODILES ON gEM (DRIOTON [1947], fig. 7)

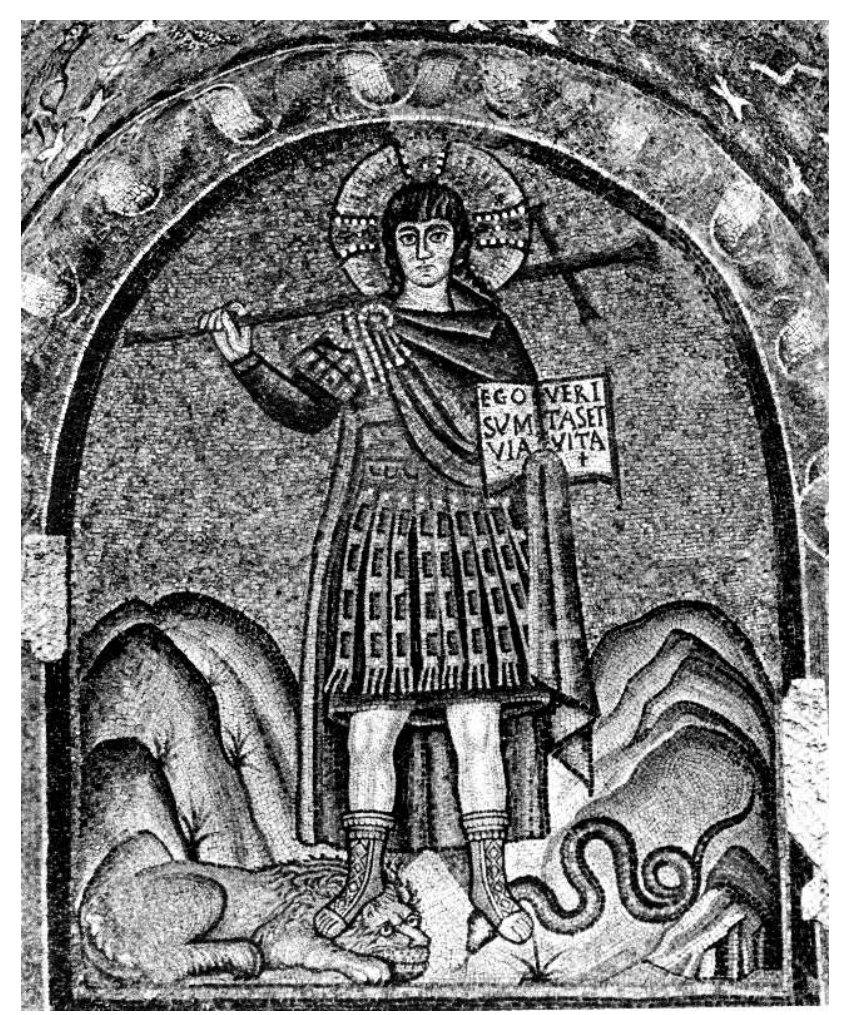

FIg. 8A. MOSAIC IN ARCHBISHOP'S CHAPEL IN RAVENNA AFTER BOVINI (1956) 


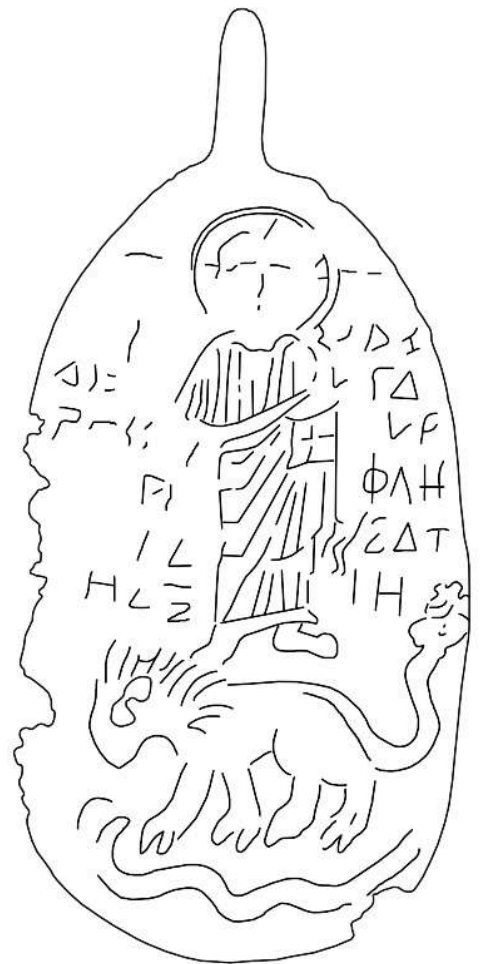

FIg. 8B. DRAWINg OF BRONZE AMULET DEPICTINg CHRIST TRAMPLINg A LION AND SNAKE (D. MERTES) 


\section{NOTES}

1. All of the drawings used as figures in this essay are the work of my colleague Dale S. Mertes of the University of Chicago.

2. This information was e-mailed to me by Marc Étienne, Conservateur en chef, Musée du Louvre, Département des Antiquités égyptiennes. I owe additional and enormous thanks to him for spending his valuable time examining the plaque closely with me, providing the photographs and for answering many other questions in person and in e-mail about it. I am grateful, also, to audiences in Bonn, Barcelona, Madrid and Chicago for helpful comments and criticisms and to Thomas Keith for his editorial help. Special thanks to Arpad Nagy and Attilio Mastrocinque, for their comments on written version and to Amalia Zomeño of the Centro de Ciencias Humanas y Sociales in Madrid for help with the Arabic. When I first presented this material in June 2015 at the conference "Ancient Egyptian and Jewish Magic" at the University of Bonn, the Arabic inscription raised some skepticism among the Egyptologists that the plaque might be a modern forgery, but that was before Marc Étienne was able to track down the full accession documents.

3. M. ÉTIENNE, HEKA: Magie et envoûtement dans l'Égypte ancienne, Paris, 2000, p.114, no. 256: “ talisman copte avec dessins magiques et inscriptions en lettres grecques et arabes."

4. ÉTIENNE, ibid., p.93: "Chnoubis se retrouve sur une plaque du Louvre avec un panthée et une représentation schématique d'un homme empoignant des serpents évoquant les stèles d'Horus sur les crocodiles."

5. V.DASEN, A.NAGY, "Le serpent léontocéphale Chnoubis et la magie de l'époque romaine impé riale," in S. BARBARA, J. TRIQUIER (eds.), Ophiaca: Diffusion etréception des savoirs antiques sur les Ophidiens, Paris, 2012 (Anthropozoologica 47.1), p. 291-314, at p. 308: "Il est facile d'y reconnaître Chnoubis sur un socle sous la forme d'un serpent lové, la tête couronnée de rayons. On devine le mot Chnoubi dans les lettres grecques gravées à son côté... Le cercle inférieur de l'avers fait référence aux gemmes magiques ophtalmologiques [...] un lézard." These are the extent of their comments on the plaque.

6. Pliny, Naturalis Historia XXIX, 130 (the amulet consists solely of gold or iron rings or of black pebbles) and Aelian, De Natura Animalium V, 47 (the amulet consists of an iron ring with lignite stone carved with a lizard, but no inscriptions). For more detailed discussion, see P. GAILLARD-SEUX, "Les maladies des yeux et le lézard vert," in G. SАВBAH (ed.), Nommer la maladie: Recherches sur le lexique gréco-latin de la pathologie, Saint-Étienne, 1997, p. 93-105; C.A. FARAONE, “A Case of Cultural (Mis)translation? Egyptian Eyes on Two Greek Amulets for Ophthalmia," in K.-D. FISCHER, B. HOLMES et al. (eds.), The Frontiers of Ancient Science: Essays in Honor of Heinrich von Staden, Berlin, 2015 (Beiträ ge zur Altertumskunde), p.93-110, at p.93-95; and T. GALOPPIN, Animaux et pouvoir rituel dans les pratiques “magiques” du monde romain, Dissertation ÉPHÉ Paris, 2016, p. 214-33.

7. Cyranides II, 8-9.

8. The manuscripts are in disagreement here about the inscriptions and their placement. D.

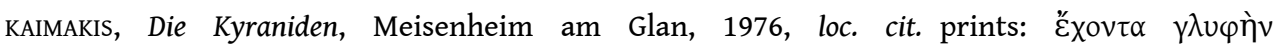

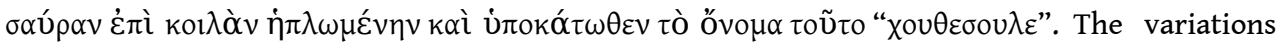
are, however, instructive: four of the twelve MSS (AGHF) finish the sentence with kai

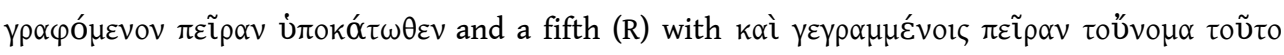

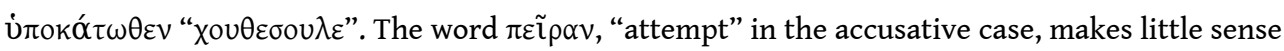
here and Kaimakis ignored it. But more than a century ago F. DE MÉLY and C.E. RUELLE, Les lapidaires de l'antiquité et du moyen âge, 3 vols. (Paris, E. Leroux, 1896-1902), vol. 2, p. 61, printed a different

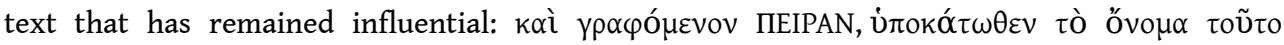
XOY $\Theta E \Sigma O Y \Lambda E$, "and being inscribed PEIRAN [and] underneath this name CHOUTHESOULE." 
Drexler and others - see discussion in C. BONNER, Studies in Magical Amulets Chiefly Graeco-Egyptian, Ann Arbor, 1950 (University of Michigan Studies, Humanistic Series 4), p. 69 - came to think (probably rightly) that ПЕIPAN was a mistake for another word: $\pi \eta \rho \alpha ́$, "maimed" or in this case "blinded", which is often (see below) inscribed piecemeal at the feet of the lizard.

9. In another version of the recipe, recorded by Marcellus of Bordeaux (VIII, 49), we find the stipulation that "the lizard must be caught and the remedy prepared in the old moon", a stipulation that suggests that the crescent moon on the stones refers to the time when the ritual was performed; see BONNER, o.c. (n. 8), p. 71.

10. The inscriptions on these lizard gems have been plausibly interpreted - see BONNER, o.c. (n. 8), p. 71-72 - as comprehensible Greek words that refer to the different stages of the ritual: the four letters on the obverse side of most of these gems seem to add up to the word $\pi \eta \rho$ á, an adjective meaning "maimed" or "blinded" in the feminine case, which perfectly describes the blinded lizard $(\sigma \alpha u ́ p \alpha)$. The inscription on the back of these gems is usually written as two words $\kappa \alpha v \theta \varepsilon$ $\sigma o u \lambda \varepsilon$, which Bonner tentatively interpreted as $\kappa \alpha v \theta \varepsilon$, $\sigma$ ' ou้ $\lambda \varepsilon\langle\imath\rangle$ “eye, heal yourself”.

11. LSJ s.v. koppa. Exekias, Lexicon s.v., describes the koppa as "a reversed rho", which might explain why it replaces the rho at least once on the plaque. Knowledge of the koppa was apparently the sign of an erudite speaker in Byzantine times, when the insult "He doesn't know the koppa!" meant "He doesn't really know Greek!" Thanks to Antony Kaldellis for these insights. 12. See notes 4 and 5 above.

13. The Paris gem is D\&D 79 (= LIM 267) and the Berlin gem is M\&M 130 (= Cbd-214). The similarities between the gems are so close that the editor of the latter, $\mathrm{H}$. ad loc. wonders whether they were produced by the same workshop.

14. S. MICHEL, Die magischen Gemmen: Zu Bildern und Zauberformeln auf geschnittenen Steinen der Antike und Neuzeit, Berlin, 2004, p. 260-261, lists seventeen examples.

15. Both the Paris and Berlin gems have on their reverse: opx $\alpha \nu \theta \omega x \rho \alpha \alpha \beta \rho \alpha \mu \alpha \omega \pi \alpha 1 \alpha \lambda \chi \mu \varepsilon$. One of the anonymous reviewers for the journal points out that another gem in Ann Arbor (SMA 92) has the same design on the obverse (Chnoubis on the pedestal) and a version of the first word of this

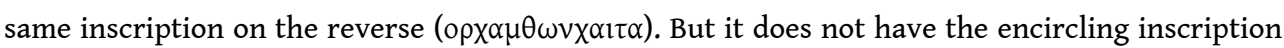
that we find on the Paris and Berlin gems.

16. The first word could be the second-person aorist imperative of the Greek verb $\dot{\rho} \varepsilon v$ u, "to flow" or "to run", addressed to the three names that follow. The first of these names, Rhêsôr, appears at the end of a similar series on the back of a gem in the Petrie Museum that shows Anubis aiming an arrow (UC 58372): "Erze Narthour Karoph Rhêsôr!"

17. Galen 12.207 (Kühn), following the translation of BONNER, Studies, 54. This is a much discussed passage, for which see most recently J. JouANNA, "Médecine rationnelle et magie : le statut des amulettes et des incantations chez Galien," REG 124 (2011), p. 47-77, esp. p. 63-65.

18. The adjective chlôros used here usually refers to pale or yellowish shades of green.

19. This is thought to be the same book of Nechepso described by Thessalus; see J.Z. SMITH, Map is not a Territory: Studies in the History of Religions, Chicago, 1978, p. 175 and I.S. MOYER, Egypt and the Limits of Hellenism, Cambridge 2011, p. 208-11 and 227-34.

20. The figure that resembles the numeral 6 , for example, could be a symbol used for hemiobelion, and the two vertical strokes could be the mark for diobelion. I thank Bill Bubelis for this information.

21. I thank Sofia Torallas Tovar for this suggestion. On Chnoubis' solar affinities, see BONNER, Studies, p. 54-60.

22. S. MICHEL, Die magischen Gemmen: Zu Bildern und Zauberformeln auf geschnittenen Steinen der Antike und Neuzeit, Berlin, 2004, p. 76.

23. It probably begins, like the other inscriptions, above the man's head with the letters XM $\Delta$ and then continues down the right side of the design, where two or three letters seem to be worn 
away and are only partially legible. The letters below his feet, however, seem to read in the reverse direction, yielding something like I $\Sigma \mathrm{E} \Lambda \Delta \mathrm{M}$. Depending on the direction, the four letters in front of the Chnoubis staff are either (reading downwards) MM $\Sigma \Sigma$ or (reading upwards) $\Lambda \Lambda \Omega \Omega$.

24. J.F. QUACK, "The So-Called Pantheos: On Polymorphic Deities in Late Egyptian Religion," Aegyptus et Pannonia 3 (2006), p. 175-190.

25. See, e.g., a number of gemstones (BM 289-292 = Cbd 675-678), that are inscribed: "Protect from every evil!", and J.H. ILIFFE, "A Neolithic Celt with Gnostic Inscriptions at Toronto," American Journal of Archaeology 35 (1931), p. 304-309. For the use of thunderstone amulets to protect against lightening, see C.A. FARAONE, "Inscribed Greek Thunderstones as House- and Body-Amulets in Roman Imperial Times," Kernos 27 (2014), p. 251-278.

26. Amalia Zomeño reports that the individual letters are not difficult to read, but they do not add up to any obvious words in Arabic nor to any phonetic transcription of the common voces magicae that show up on the magical gems.

27. After E. DRIOTON, "Un médaillon d'Horus sur les crocodiles," Annales du Service des Antiquités d' Égypte 45 (1947), p. 83-84, at p. 84, fig. 7.

28. J. SPIER, "An Antique Magical Book for Making Sixth-Century Byzantine Amulets?," in V. DASEN and J.-M. SPEISER (eds.), Les savoirs magiques et leur transmission de l'Antiquité à la Renaissance, Florence, 2014, p. 48-49 with fig. 3. The much abraded text on either side of Jesus reads in part: "Gabriel, Ouriel, Raphael, protect...!"

29. The text that surrounds this scene is difficult to read, but a possible transcription might be: $\Sigma K O \Pi N \Pi \triangle O O N O O A O \Phi I \Omega N-\Sigma \Lambda N \Lambda \Omega K \Sigma O M I \Phi O$. Given the iconography of the scene within the circle traced by these letters, one might suggest that the first five letters $(\Sigma \mathrm{KO} N \mathrm{~N})$ are a truncated version of $\sigma \kappa o\langle\rho\rangle \pi\langle i ́ o\rangle \nu$ ("scorpion") or $\sigma \kappa o\langle\rho\rangle \pi\langle i \omega\rangle\rangle$ ("of the scorpions"), which is then perhaps followed by a scrambled version ( $\triangle \Delta \mathrm{OON}$ ) of the word $\pi \circ \delta \tilde{\omega} v$ ("of the feet"), and then (after two or three letters) the word $O \Phi I \Omega N$, which with a change of a single letter gives us the genitive plural of "snakes" (ó $\varphi \varepsilon ́ \omega v)$. This is, of course, extremely speculative

and, because this image of Horus hardly ever appears on gems and because are no similar texts on the extant magical gems with other images, it seems safe to conclude that - like the novel additions to the texts that surround the lizard and the Chnoubis images - these letters are a nonsensical invention designed to make the overall design similar to those on the obverse.

30. The lizard, however, $5 \mathrm{~cm}$ long, nearly twice as long as the lizards we find on the magical gems.

31. Curative handbooks: $S M 78 \mathrm{col}$. ii $\left(2^{\text {nd }}-3^{\text {rd }} C E\right.$, Oxyrhynchus $)=P G M$ XCVII $\left(3^{\text {rd }}-4^{\text {th }} C E\right)$, which has five recipes for eye-disease, PGM LXIII $\left(2^{\text {nd }}-3^{\text {rd }} C E\right)$, two contraceptive recipes, $S M 88\left(4^{\text {th }} \mathrm{CE}\right.$, Oxyrhynchus), two for skin disease or SM $89\left(4^{\text {th }} \mathrm{CE}\right)=$ PGM CXII $\left(4^{\text {th }}-5^{\text {th }} C E\right)$, two for scorpions. Lapidary Handbook: S\&D 26-39.

32. G. BOHAK, Ancient Jewish Magic: A History, Cambridge, 2008, p. 149-165.

33. See A.A. BARB, "Three Elusive Amulets," Journal of the Warburg and Courtauld Institutes 27 (1964), p. 1-22, at p. 16-17, and three articles by G. VIKAN: "Art, Medicine, and Magic in Early Byzantium," Dumbarton Oaks Papers 38 (1984), p. 65-86; “Art and Marriage in Early Byzantium,” Dumbarton Oaks Papers 44 (1990), p. 145-163; "Two Byzantine Amuletic Armbands and the Group to which They Belong," Journal of the Walters Art Gallery 49-50 (1991-92), p. 35-51. Now see also DASEN - NAGY, "Le serpent léontocéphale Chnoubis," p. 307-308.

34. VIKAN, “Art, Medicine, and Magic," p. 75-78. 


\section{ABSTRACTS}

A copper plaque purchased in the $19^{\text {th }}$ century in Egypt is engraved on both sides with six images, all but one encircled by Greek letters or symbols. Because these designs are frequently found on magical gems of the Roman period, it has been suggested in passing that the plaque is a composite amulet of sorts, but I argue instead that it is a "pattern-book" originally designed to be hung on the wall of a studio in order to remind an artisan how to make curative amulets for eyedisease and other problems or protective talismans for driving away noxious animals. At some point in their transmission these designs seem to have been altered by someone who suppressed some of the more obvious pagan details (e.g. animal-headed gods) and added Christian motifs i.e. Horus treading on the crocodiles becomes Christ treading on a lion and a snake, as he does in Psalm 90.14. The plaque in the Louvre is an early medieval version of this pattern book: the Arabic inscription in the top left corner of the obverse suggests that it was manufactured in the $8^{\text {th }}$ or $9^{\text {th }}$ century CE.

Une plaque en cuivre achetée au XIX ${ }^{e}$ siècle en Égypte porte six images gravées sur ses deux faces, toutes entourées de lettres grecques et de symboles, à l'exception d'une seule. Comme ces dessins sont fréquemment attestés sur des gemmes magiques de la période romaine, on a suggéré en passant que la plaque était une amulette composite de sorts, mais le présent article argumente en faveur d'un « livre de modèles » originellement destiné à être accroché au mur d'un atelier afin de rappeler à un artisan comment réaliser des amulettes pour guérir les maladies des yeux et d'autres problèmes, ou bien des talismans de protection pour repousser des animaux nuisibles. À un certain moment de leur transmission, ces dessins semblent avoir été altérés par quelqu'un qui a supprimé certains des détails les plus clairement païens (par exemple, les dieux à tête animale) et ajouté des motifs chrétiens - ainsi, Horus terrassant des crocodiles devient le Christ terrassant un lion et un serpent comme dans le Psaume 9.14. La plaque du Louvre est une version du haut moyen âge de ce livre de modèles : l'inscription arabe dans le coin supérieur gauche du revers suggère qu'elle a été fabriquée $\mathrm{au} \mathrm{VIII}^{\mathrm{e}}$ ou au $\mathrm{IX}^{\mathrm{e}}$ siècle.

\section{AUTHOR}

\section{CHRISTOPHER A. FARAONE}

University of Chicago

cf12@uchicago.edu 